\title{
Organogênese direta de explantes cotiledonares e regeneração de plantas de mogango
}

\author{
Direct organogenesis of cotyledon explants and plant regeneration of squash
}

\author{
André Luís Lopes da Silva ${ }^{1}$ Dilson Antônio Bisognin ${ }^{1 *}$ \\ Cícero João Barriquello ${ }^{1}$ Júnior Girotto $^{1}$
}

\begin{abstract}
- NOTA -
\section{RESUMO}

Os objetivos foram induzir a organogênese direta de explantes cotiledonares de mogango e estudar a regeneração de plântulas completas a partir das brotações adventícias. Foram utilizados cotilédones como explantes, originados das plântulas de mogango com 20 dias após a semeadura. O meio basal utilizado foi o MS (MURASHIGE \& SKOOG, 1962) suplementado com $30 \mathrm{~g} \mathrm{~L}^{-1}$ de sacarose e $7 \mathrm{~g} \mathrm{~L}^{-1}$ de agar. Foram testadas as concentrações de 6-benzilaminopurina (BAP) de $0 ; 0,5 ; 1,0$ e 2,0mg $L^{-1}$. Explantes de ápices caulinares $e$

of agar. The 6-benzilaminopurina (BAP) concentrations of 0 , $0.5,1.0$ and $2.0 \mathrm{mg} \mathrm{L}^{-1}$ were tested. Apical and nodal explants from adventitious shoots were transferred to MS medium supplemented with $30 \mathrm{~g} \mathrm{~L}^{-1}$ of sucrose and $7 \mathrm{~g} \mathrm{~L}^{-1}$ of agar. Increasing BAP concentrations in the MS medium enhance the percentage of adventitious shoot and reduce the percentage of root organogenesis of squash cotyledon explants. Apical and nodal explants from adventitious shoot regenerated plantlets with roots in MS medium without growth regulators. High percentage of plantlet rooting depends upon the size of the explants.
\end{abstract} segmentos nodais de brotações adventícias foram então cultivados em meio MS suplementado com $30 \mathrm{~g} \mathrm{~L}^{-1}$ de sacarose e $7 \mathrm{~g} \mathrm{~L}^{-1}$ de agar. Maiores concentrações de BAP no meio MS promoveram um aumento da percentagem de explantes cotiledonares com brotações adventícias e uma redução da percentagem de enraizamento. Explantes de segmentos nodais e ápices caulinares oriundos de brotações adventícias cresceram e enraizaram em meio MS sem reguladores de crescimento. Altas percentagens de enraizamento dependem do tamanho dos explantes utilizados.

Palavras-chave: Cucurbita pepo, 6-benzilaminopurina, cultivo e enraizamento in vitro, explantes.

\section{ABSTRACT}

The objectives were to induce direct organogenesis of squash cotyledons and to study the regeneration of complete plantlets from adventitious shoot. Cotyledon explants of 20day seedlings were cultured in MS (MURASHIGE \& SKOOG, 1962) medium supplemented with $30 \mathrm{~g} \mathrm{~L}^{-1}$ of sucrose and $7 \mathrm{~g} \mathrm{~L}^{-1}$
Key words: Cucurbita pepo, 6-benzilaminopurine, in vitro culture and rooting, explants.

Vários estudos morfogênicos in vitro já foram realizados com a espécie Cucurbita pepo, como a micropropagação a partir de segmentos nodais (JURETIC et al., 1989) e ápices caulinares (PINK \& WALKEY, 1984). Plântulas haplóides já foram obtidas através da cultura de anteras (METWALLY et al., 1998). Além disso, explantes cotiledonares têm sido utilizados com sucesso para a indução de morfogênese direta e indireta em várias espécies de cucurbitáceas. Explantes cotiledonares da cv. Pusa Madhuras de melão (Cucumis melo) enraizaram e formaram calos, que regeneraram gemas e brotações axilares (JAIN \& MORE,

${ }^{1}$ Departamento de Fitotecnia, Universidade Federal de Santa Maria (UFSM), 97105-900, Santa Maria, RS, Brasil. Email:dilsonb@smail.ufsm.br. * Autor para correspondência. 
1992). Cotilédones de quatro linhagens tetraplóides de melancia (Citrulus lanatus) produziram brotações adventícias a partir da região basal (COMPTON \& GRAY, 1994). O ácido 2,4 diclorofenoxiacético (2,4 D) ou o ácido indolbutírico (AIB) combinado com altas concentrações de sacarose foram utilizados para a produção de embriões somáticos em explantes cotiledonares de pepino (Cucumis sativus) (LOU et al., 1996).

Os objetivos deste trabalho foram induzir a organogênese direta de explantes cotiledonares de mogango e estudar a regeneração de plântulas completas a partir das brotações adventícias.

Os experimentos foram conduzidos no Núcleo de Biotecnologia e Melhoramento de Plantas do Departamento de Fitotecnia da UFSM. Sementes de mogango da cultivar Enrugado Verde foram imersas em álcool 70\% durante 3min, lavadas três vezes com água destilada e autoclavada, imersas novamente numa solução de hipoclorito de sódio ( $\mathrm{NaOCl}$ ) 2,5\% durante 20min e lavadas três vezes em água destilada e autoclavada. $\mathrm{O}$ meio de cultura para a germinação foi constituído de água destilada e $30 \mathrm{~g} \mathrm{~L}^{-1}$ de sacarose, sendo solidificado com $7 \mathrm{~g} \mathrm{~L}^{-1}$ de agar. $\mathrm{O} \mathrm{pH}$ foi ajustado para 5,7. Aos 20 dias após a semeadura, cotilédones inteiros foram usados como explantes para a indução de brotações adventícias. O meio basal utilizado foi o MS (MURASHIGE \& SKOOG, 1962) suplementado com $30 \mathrm{~g} \mathrm{~L}^{-1}$ de sacarose e $7 \mathrm{~g} \mathrm{~L}^{-1}$ de agar. $\mathrm{O} \mathrm{pH}$ foi ajustado para 5,7. Os tratamentos consistiram das concentrações de 0 (testemunha); 0,$5 ; 1,0$ e $2,0 \mathrm{mg} \mathrm{L}^{-1}$ de 6 benzilaminopurina (BAP) no meio MS. Aos 12 dias de cultivo foram avaliados o número e a percentagem de brotações adventícias formadas por explante cotiledonar e a percentagem de explantes com raízes.

As brotações adventícias foram utilizadas como fontes de explantes de ápices caulinares e segmentos nodais. Os explantes de ápices caulinares foram separados por tamanho de aproximadamente 1,5; 2,5 e 3,5cm de comprimento. Os explantes de segmentos nodais foram separados de acordo com o seu tamanho, ficando em grupos com aproximadamente 0,$7 ; 1,2 ; 1,7 ; 2,2 ; 2,7$ e 3,2cm de comprimento. Todos os explantes foram cultivados em meio MS suplementado de $30 \mathrm{~g} \mathrm{~L}^{-1}$ de sacarose e solidificado com $7 \mathrm{~g} \mathrm{~L}^{-1}$ de agar. $\mathrm{O}$ pH foi ajustado para 5,7. Aos 19 dias de cultivo, foram avaliados a percentagem de enraizamento, de oxidação em alguma região do tecido e de sobrevivência, o número de brotações e de folhas e o comprimento dos brotos $(\mathrm{cm})$, considerando os explantes de ápice caulinar e segmento nodal de todos os comprimentos avaliados.
As unidades experimentais foram mantidas em sala de crescimento com a temperatura de $25^{\circ} \mathrm{C} \pm 2^{\circ} \mathrm{C}$ e fotoperíodo de 16 horas, sob intensidade luminosa média de $20 \mu \mathrm{M} \mathrm{M}^{-2} \mathrm{~S}^{-1}$ obtida por lâmpadas fluorescentes brancas. O delineamento utilizado foi o inteiramente casualizado, com quatro repetições de dez explantes. Os dados foram submetidos à análise de variância e as médias de tratamento plotadas em gráfico com os respectivos desvios. As análises foram realizadas com o auxílio do programa GENES (CRUZ, 2001).

As diferentes concentrações de BAP adicionadas ao meio MS não afetaram a sobrevivência dos explantes cotiledonares nem a produtividade de brotações adventícias, sendo obtida uma média de uma brotação por explante. As brotações adventícias foram formadas a partir da região basal dos explantes cotiledonares independentemente da concentração de BAP no meio, sendo algumas destas brotações ligadas ao sistema radicular. O aumento das concentrações de BAP no meio MS promoveu o aumento da percentagem de explantes cotiledonares com brotações adventícias, atingindo um máximo de $70 \%$ na concentração de 2,0 $\mathrm{mg} \mathrm{L}^{-1}$ de BAP (Figura 1). Entretanto, o aumento das concentrações de BAP no meio promoveu uma redução linear da percentagem de enraizamento das brotações adventícias. A menor percentagem de enraizamento (60\%) foi obtida na concentração de $2,0 \mathrm{mg} \mathrm{L}^{-1}$ de BAP.

$\mathrm{O}$ fato de que o aumento da concentração de BAP no meio MS promoveu um aumento de explantes com brotações adventícias está de acordo com os resultados obtidos por ANANTHAKRISHNAN

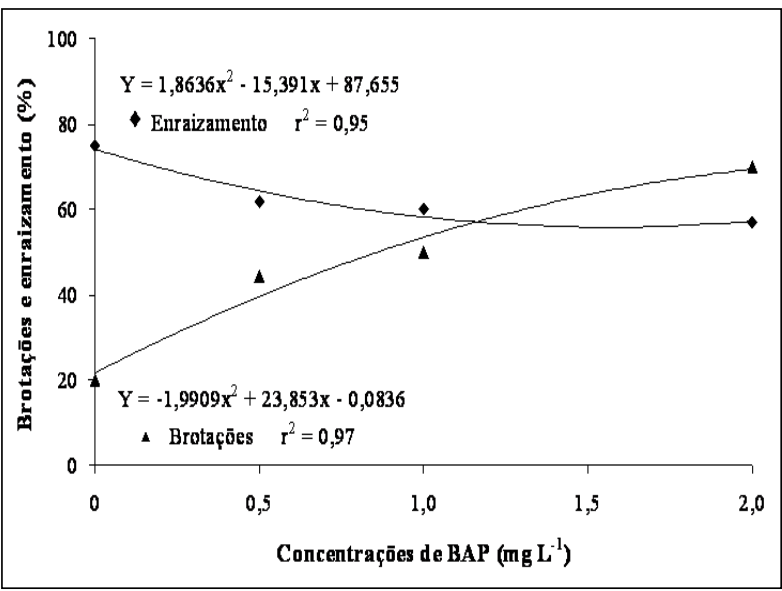

Figura 1 - Percentagem de brotações adventícias e enraizamento in vitro promovidas pela adição de diferentes concentrações de 6-benzilaminopurina (BAP) ao meio de cultura MS (MURASHIGE \& SKOOG, 1962) em explantes cotiledonares de mogango. Santa Maria, RS, 2004.

Ciência Rural, v.36, n.3, mai-jun, 2006. 
et al. (2003) com a cultivar Ma'yan de C. pepo, segundo os quais $88 \%$ dos explantes cotiledonares produziram brotações adventícias com a adição de $1,0 \mathrm{mg} \mathrm{L}^{-1}$ de BAP. Nas cultivares de melão, Yellow Queen, Yellow King e AF-222 foram obtidas $80 \%$ de brotações adventícias com as concentrações de BAP entre 0,5 e 1,0mg L-1 (STIPP et al., 2001). Neste experimento, também ocorreu a indução de brotações adventícias na ausência de reguladores de crescimento, o que concorda com os resultados obtidos com a variedads inodorus, de melão (STIPP et al., 2001), e com : cultivar Sürme, de melancia (PIRINÇ et al., 2003) Em três cultivares de $\boldsymbol{C}$. pepo, foi observadc que parte dos cotilédones enraizaram sem afeta o aparecimento de brotações adventícia: (ANATHAKRISHNAN et al., 2003). A induçãc de raízes também foi observada na cultiva Rolet, de $\boldsymbol{C}$. pepo (ABRIE \& VAN STADEN 2001). Portanto, a formação de raízes a partir dı explantes cotiledonares parece ser comum en cucurbitáceas, entretanto, como mostrado nestı trabalho, a percentagem de enraizamento podı ser negativamente afetada pela adição de BAI ao meio de cultura. Por outro lado, existen genótipos que não respondem à organogênest direta, como verificado nas cultivares A-line e Chicago, de C. maxima, e na cultivar Rolet, de C. pepo, mesmo sob a influência de diversas concentrações (0-10 $\left.\mathrm{mg} \mathrm{L}^{-1}\right)$ das citocininas BAP, 6-furfurilaminopurina (KIN), isopenteniladenina (2iP) e tidiazuron (TDZ), isoladas ou combinadas com as concentrações de 0 a 1,0mg $\mathrm{L}^{-1}$ de ácido indolacético (AIA) (ABRIE \& VAN STADEN, 2001).

O aumento do tamanho de explantes, tanto de ápices caulinares quanto de segmentos nodais, promoveu um aumento da percentagem de enraizamento (Figura 2). Explantes de ápices caulinares de 2,5 e 3,5cm de comprimento apresentaram um enraizamento de 100\% (Figura 2A), demonstrando a importância da gema apical como região produtora de auxinas para promover o enraizamento. Entretanto, explantes de segmentos nodais de 3,2cm de comprimento proporcionaram um enraizamento de apenas 70\% (Figura 2B). Os ápices caulinares proporcionaram um maior número de brotações e de folhas, maior percentagem de enraizamento e de oxidação nos tecidos e regeneraram brotações mais compridas do que os explantes de segmentos nodais. Todos os explantes sobreviveram no meio de cultura até a avaliação, independente do tipo usado (dados não apresentados). Resultados

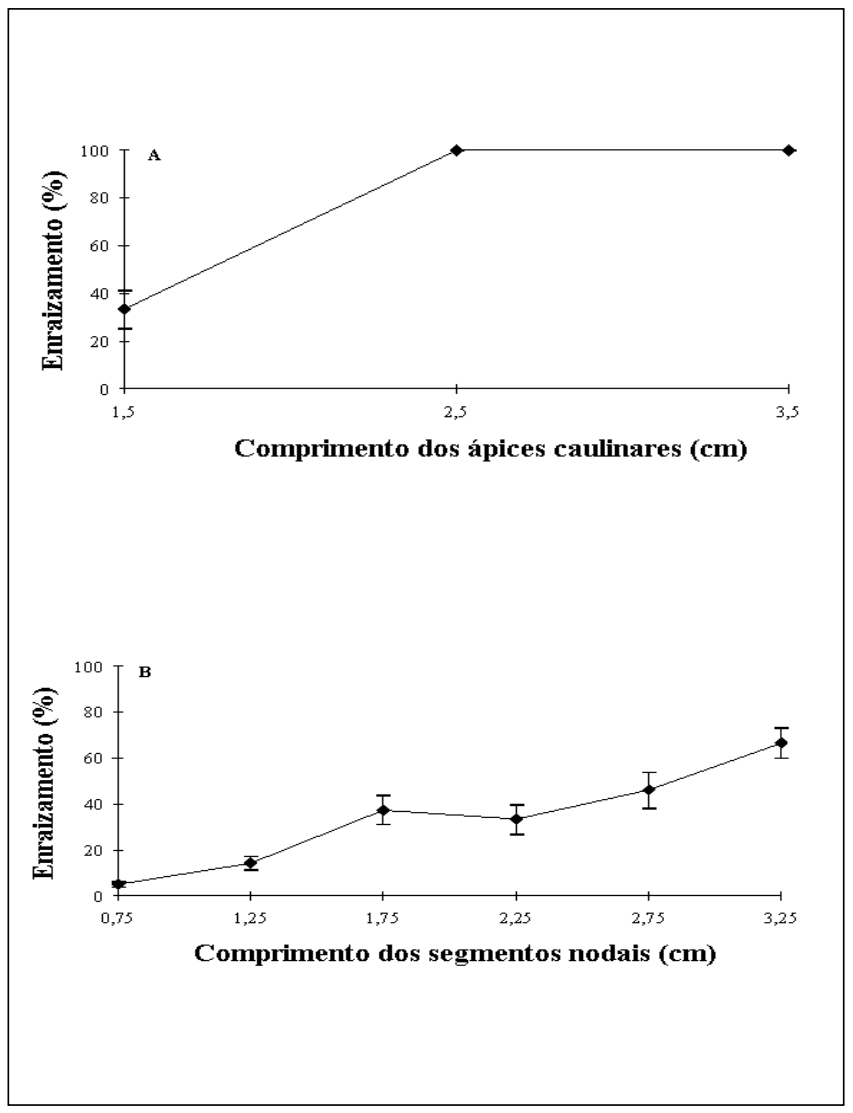

Figura 2 - Percentagem de enraizamento in vitro de ápices caulinares (A) e segmentos nodais (B) de diferentes tamanhos de explantes de brotações adventícias produzidas a partir de cotilédones de mogango. Santa Maria, RS, 2004.

similares foram obtidos com a cultivar Sürme, de melancia, na qual altas percentagens de enraizamento somente foram obtidas com explantes maiores do que 1,6cm de comprimento (PIRINÇ et al., 2003). O percentual de enraizamento também pode ser influenciado pela ação de reguladores de crescimento, como demonstrado em melancia pela adição de ácido naftalenoacético (ANA) ao meio de cultura (COMPTON \& GRAY, 1993; PIRINÇ et al., 2003). Na espécie de Benincasa hispida, também pertencente à família Cucurbitaceae, o AIB foi superior ao ANA quanto a aumentar o enraizamento de brotações adventícias (THOMAS \& SREEJESH, 2004).

Os resultados deste trabalho mostram claramente que a organogênese direta de brotações adventícias de cotilédones de mogango pode ser induzida sem a necessidade de reguladores de crescimento. A indução pode ser maximizada com a adição de BAP ao meio de cultura; porém, altas concentrações de BAP não afetam o número de 
brotações por explante cotiledonar. A regeneração in vitro de ápices caulinares e segmentos nodais sem o uso de reguladores de crescimento facilita a propagação massal de mogango e reduz os custos, oferecendo uma excelente oportunidade para explorar a cultura de tecidos como ferramenta auxiliar em programas de melhoramento genético. O tamanho de explante, tanto de ápices caulinares quanto de segmentos nodais, é um fator importante a ser considerado para a obtenção de altas percentagens de enraizamento.

\section{REFERÊNCIAS}

ABRIE, A.L.; VAN STADEN, J. Development of regeneration for selected cucurbit cultivars. Plant Growth Regulators, v.35, p.263-267, 2001

ANANTHAKRISHNAN, G. et al. Shoot production in squash (Cucurbita pepo) by in vitro organogenesis. Plant Cell Reports, v.21, p.739-746, 2003.

COMPTON, M.E.; GRAY, D.J. Shoot organogenesis and plant regeneration from cotyledons of diploid, triploid, and tetraploid watermelon. Journal of American Society of Horticultural Science, v.118, n.1, p.151-157, 1993.

COMPTON, M.E.; GRAY, D.J. Adventitious shoot organogenesis and plant regeneration from cotyledons of tetraploid watermelon. HortScience, v.29, n.3, p.211-213, 1994.

CRUZ, C.D. Programa genes versão windows: aplicativo computacional em genética e estatística. Viçosa: UFV, 2001. 648p.
JAIN, J.; MORE, T.A. In vitro regeneration in Cucumis melo cv. Pusa Madhuras. Cucurbit Genetics Cooperative Reports, v.15, p.62-64, 1992.

JURETIC, B. et al. In vitro clonal multiplication of Cucurbita pepo by single-node culture. Acta Botanica Croatica, v.48, p.27-34, 1989.

LOU, H. et al. Influence of sucrose concentration on in vitro morphogenesis in cultured cucumber cotyledon explants. Journal of Horticultural Science, v.71, n.3, p.497-502, 1996.

METWALLY, E.I. et al. Haploid plantlets derived by anther culture of Cucurbita pepo. Plant Cell Tissue and Organ Culture, v.52, p.171-176, 1998.

MURASHIGE, T.; SKOOG, F. A revised medium for rapid growth and bioassays with tobacco tissue cultures. Physiologia Plantarum, v.15, p.473-497, 1962.

PINK, D.A.C.; WALKEY, D.G.A. Rapid propagation of Cucurbita pepo L. by culture of meristem tips. Hortscience, v.24, p.107-114, 1984.

PIRINÇ, V. et al. Adventitious shoot organogenesis and plant regeneration from cotyledons of diploid diyarbakir watermelon (Citrullus lanatus cv. Sürme). Turkish Journal of Biology, v.27, p.101-105, 2003.

STIPP, L.C.L. et al. In vitro morphogenesis of Cucumis melo var. inodorus. Plant Cell, Tissue and Organ Culture, v.65, p.81-89, 2001.

THOMAS, T.D.; SREEJESH, K.R. Callus induction and plant regeneration from cotyledonary explants of ash gourd (Benincasa hispida L.). Scientia Horticulturae, v.100, p.359-367, 2004. 